\title{
Apical Meristem-Targeted In Planta Transformation Strategy: an Overview on its Utility in Crop Improvement
}

\author{
Karthik Kesiraju and Rohini Sreevathsa* \\ ICAR-National Research Centre on Plant Biotechnology, India
}

Submission: June 23, 2017; Published: July 17, 2017

"Corresponding author: Rohini Sreevathsa, ICAR-National Research Centre on Plant Biotechnology, LBS Centre, Pusa Campus, New Delhi, India, Tel: +9101125842787; Email: rohinisreevathsa@gmail.com

\begin{abstract}
Transgenic technology has provided an unprecedented boost to plant biotechnology by the development of various methods to engineer plants with desired traits. Though plant breeding has been successful, trait transfer is limited to different genotypes within the same species, thus highlighting the need of techniques to engineer the plants for greater agronomical value. One such technique has been the non-tissue culturebased In planta transformation strategy to engineer recalcitrant crops that are difficult to regenerate. In this review, we have focussed on the usefulness of one of the In planta transformation protocols that targets the T-DNA to differentiating shoot apical meristem. This protocol proves to be advantageous to generate transgenic plants that can alleviate the effects of both biotic and abiotic stresses posed by the environment and help in productivity increase.
\end{abstract}

Keywords: In planta transformation technique; Chimeric plants; Tissue culture; Regeneration; Biotic and abiotic stresses

\section{Introduction}

Biotechnological approaches for crop improvement have gained momentum following the introduction of transgenics. However, one of the bottlenecks in the successful deployment of genes through transgenesis is the amenability of the target crops to regeneration. Not all economically important crop plants are regeneration-friendly. Such plants are labelled as "difficult to regenerate". As an alternative, transformation strategies that totally avoid or minimise the tissue culture steps came into existence [1]. These strategies are commonly called as 'in planta transformation methodologies' as they surpass the regeneration step. In planta transformation protocols have gained much appreciation in the present days due to the viability and ease in the generation of transgenic plants in vitro by following simple techniques that are efficient, quick and tissue cultureindependent. These techniques also avoid the laborious, time consuming tissue culture practices for crop improvement and have evidenced the potential of genetic engineering in modifying the crops to enhance crop productivity by accelerating disease resistance, pest resistance and stress mitigation by orienting quality changes in the seeds of the plant.
Though physical gene transfer techniques like gene gun, biolistics, micro-injection have the ability to mediate gene transfer to produce plants with desired traits, these sophisticated techniques require expensive equipment and is skill demanding. The conventional plant transformation methods use the biological transfer agent, Agrobacterium [2] the only natural genetic engineer that has the ability to engineer the plant genome. The major disadvantage of tissue culture based transformation methods are that they are time consuming, lead to variations that affect both qualitative and quantitative traits of the genetically modified plants and may or may not produce gametes that carry genetic material to the subsequent generations.

Development of a large number of uniform plants in vitro in short time, with less labour efforts and minimal reagent requirements are the major advantages ofin planta transformation protocols. These methods have been commonly preferred and used for the transformation of genes into recalcitrant plant species. The tissue culture-independent techniques were 
first initiated in Arabidopsis thaliana and research with this plant has thrown new insight for the development of high throughput transformation methods referred to as the in planta transformation protocols [3] that avoid/eliminate the plant tissue culture procedures. Agrobacterium mediated in planta transformation methods in Arabidopsis [4] such as "clip ' $n$ ' squirt" [5] and vacuum infiltration [6] have been successfully used by many researchers. The main advantage of in planta transformation is the ability to produce large number of viable plants that can be screened to achieve transgenic plants which have suffered minimum genetic damage and carry a single insertion event $[7,8]$.

Our group has been working on in planta transformation for the last two decades and we have focussed on the use of differentiating shoot apical meristem for successful transformation [9]. The apical meristem can be considered as the right stage for receiving transgenes as these cells would eventually lead to growth and development of the plant [10] and lead the T-DNA to germ line cells and further into the next generation. Agrobacterium infection is directed towards the plumule, cotyledonary node and surrounding regions of aseptically germinated two day old young seedlings (Figure 1). Wounded tobacco leaf extract is added to Winans' AB minimal media to improve the transformation efficiency by increasing the virulence of the vir genes by the phenolic compounds present in the mature tobacco leaves. The seedlings are then transferred to the trays or cups containing autoclaved soilrite and grown in culture chambers for 7-8 days under $16 \mathrm{~h}$ photo period. The recovered plants are then transferred to the pots containing soil and grown to obtain mature plants. The seeds of these chimeric plants are then screened in the presence of selective antibiotics to obtain the transformed plants that can be characterised for the presence of the transgene. The methodology helps in the development of a large number of primary transformants. In order to tackle the large number of seeds to be screened in T1 generation, high throughput screening strategies are in place for efficient identification of putative transformants [11- 34].

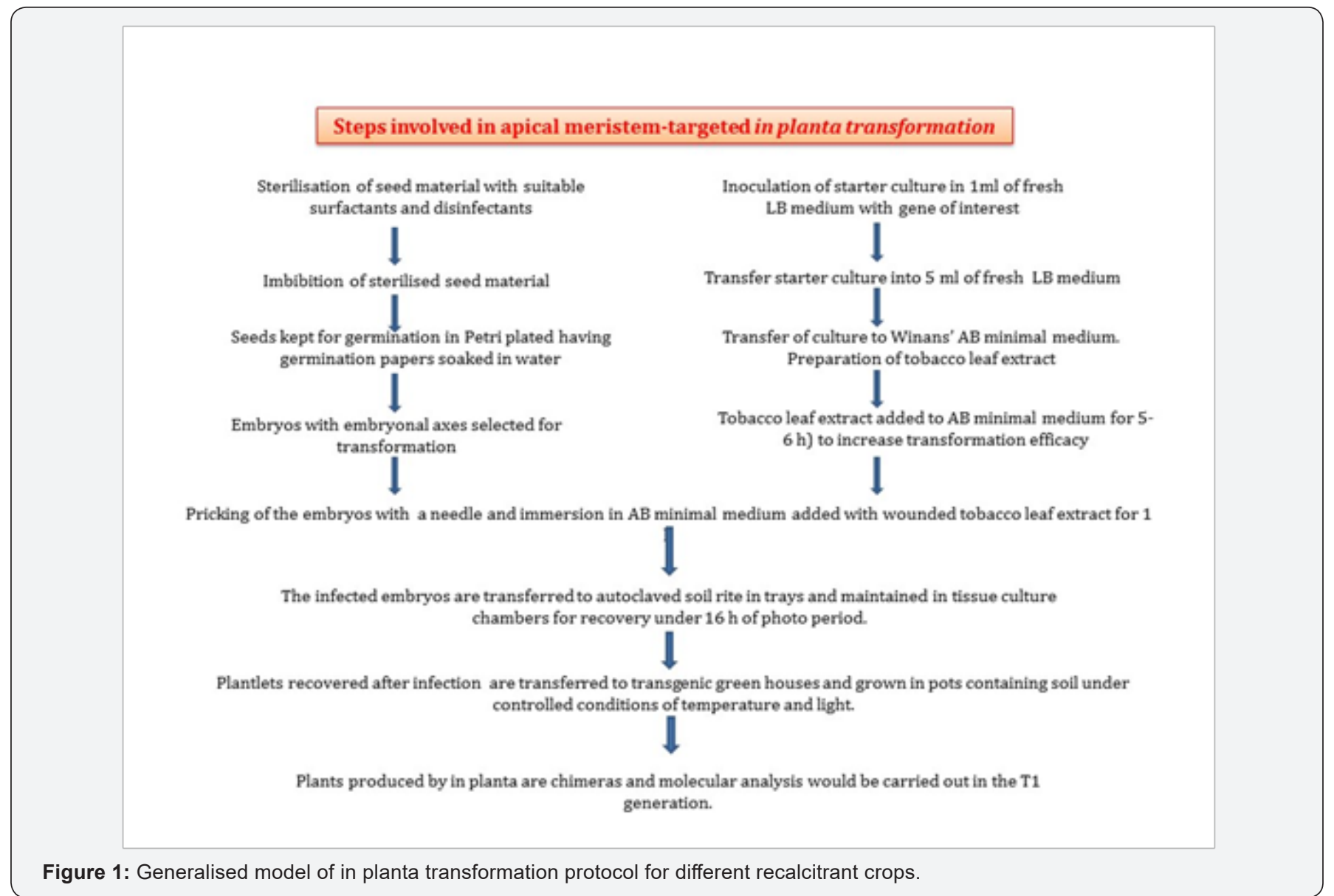

Usefulness of the Apical Meristem-Targeted in Planta Transformation Strategy

Since the conceptualization of the apical meristem strategy for transformation, its feasibility has been demonstrated in a wide range of crop species (Table 1). Unambiguous demonstration of the integration and stable inheritance of the T-DNA has been successfully provided using marker genes like gus and $g f p$.

Further, the technique has also been used to develop transgenic plants in economically important crops to combat both biotic and abiotic stresses (Table 1). The interpretation 
of results from these studies have shown that the transgenic plants do possess superior traits when compared to the nontransformed control plants, thus proving ability of the technique to generate transgenic plants with traits of interest. The methodology can therefore be used to engineer a variety of crop plants of agronomical value by adopting a few modifications and standardisations to the generalised protocol according to the crop species that are to be transformed.

Table 1: List of transgenic crops generated using the apical meristem targeted in planta transformation.

\begin{tabular}{|c|c|c|c|}
\hline SI no. & Crop & Gene & Reference \\
\hline \multicolumn{4}{|c|}{ Standardization } \\
\hline 1 & Sunflower & uid A & [12] \\
\hline 2 & Safflower & uid A & [13] \\
\hline 3 & Peanut & uid $\mathrm{A}$ & [14] \\
\hline 4 & Cotton & uid A & [15] \\
\hline 5 & Capsicum & uid A & [16] \\
\hline 6 & Capsicum & gfp & [17] \\
\hline 7 & Pigeon pea & uid A & [18] \\
\hline 8 & Field bean & uid $\mathrm{A}$ & [19] \\
\hline \multicolumn{4}{|c|}{ Abiotic stress } \\
\hline 9 & Groundnut & epsps & {$[20]$} \\
\hline 10 & Chick pea & epsps & [21] \\
\hline 11 & Rice & AVP1 & {$[22]$} \\
\hline 12 & Rice & AtPCS & [23] \\
\hline 13 & Rice & NHX1 & {$[24]$} \\
\hline 14 & Chili & PDH45 & [25] \\
\hline \multicolumn{4}{|c|}{ Biotic stress } \\
\hline 15 & Groundnut & Cry1X & [26] \\
\hline 16 & Chick pea & Cry1AcF & [27] \\
\hline 17 & Groundnut & $\beta$-1,3-glucanase & [28] \\
\hline 18 & Safflower & Chi11 & [29] \\
\hline 19 & Castor & Cry1AcF & {$[30]$} \\
\hline 20 & Sunflower & $\beta$-1,3-glucanase & [31] \\
\hline 21 & Field bean & Cry1AcF & {$[32]$} \\
\hline 22 & Pigeon pea & Cry1AcF & [33] \\
\hline 23 & Sunnhemp & FMDV 1D & {$[34]$} \\
\hline
\end{tabular}

\section{Discussion}

The transformation strategy under focus is an addition to the very many non-tissue culture strategies already available. It can be extrapolated to generate stable transgenic plants in both monocots and dicots. This technique in spite of its ease has a limitation, the production of chimeras', which can be successfully screened with the adaption of standardised screening protocols. This technique can also be optimised to produce transgenics in crops like wheat that have been reported to have very low transformation efficiency. The production decline due to yield losses caused by insect pests and various environment clues can be mitigated by transferring different genes into the plants using the strategy for management of biotic and abiotic stresses. This technology is simple with a good ease of adoption and high rate of success.

\section{References}

1. Rohini VK and Rao KS (2002) In planta strategy for gene transfer into plants: embryo transformation. Physiology and Molecular Biology of Plants 8(2): 161169.

2. Hoekema A, Hooykaas PJ, Schilperoort RA, Leiden R, Scilperoort R (1992) Process for introducing foreign DNA into the genome of plants. US Patent 5: 149-645.

3. Azpiroz-Leehan R, Feldmann KA (1997) T-DNA insertion mutagenesis in Arabidopsis: going back and forth. Trends in Genet 13(4): 152-156.

4. Bechtold N, Ellis J, Pelletier G (1993) In planta Agrobacterium mediated gene transfer by infiltration of adult Arabidopsis thaliana plants. Comptes rendus de l'Académie des sciences. Série 3, Sciences de la vie 316(10): 1194-1199.

5. Chang SS, Park SK, Kim BC, Kang BJ, Kim DU, et al. (1994) Stable genetic transformation of Arabidopsis thaliana by Agrobacterium inoculation in planta. The Plant Journal 5(4): 551-558.

6. Bechtold N, Pelletier G (1998) In planta Agrobacterium mediated transformation of adult Arabidopsis thaliana plants by vacuum infiltration. Arabidopsis protocols 82: 259-266.

7. Birch RG (1997) Plant transformation: problems and strategies for practical application. Annual review of plant biology 48(1): 297-326.

8. Hansen G, Wright MS (1999) Recent advances in the transformation of plants. Trends in plant sci 4(6): 226-231.

9. Rao KS, Rohini VK (1999) Agrobacterium- mediated Transformation of Sunflower (Helianthus annuus L.): A Simple Protocol. Annals of Botany 83(4): 347-354.

10. Chowrira GM, Akella V, Lurquin PF (1995) Electroporation mediated gene transfer into intact nodal meristems in planta. Molecular Biotechnology 3(1): 17-23.

11. Shivakumara TN, Sreevathsa R, Dash PK, Sheshshayee MS, Papolu PK et al (2017) Overexpression of Pea DNA Helicase 45 (PDH45) imparts tolerance to multiple abiotic stresses in chili (Capsicum annuum L.). Scientific Reports 7: 2760.

12. Rao KS, Rohini VK (1999) Agrobacterium-mediated Transformation of Sunflower (Helianthus annuus L.): A Simple Protocol. Annals of Botany 83(4): 347-354.

13. Sankararao K, Rohini VK (1999) Gene transfer into Indian cultivars of safflower (Carthamus tinctorius L.) using Agrobacterium tumefaciens. Plant Biotechnology 16(3): 201-206.

14. Rohini VK, Rao KS (2001) Transformation of peanut (Arachis hypogaea L.) with tobacco chitinase gene: variable response of transformants to leaf spot disease. Plant Sci 160(5): 889-898.

15. Keshamma E, Rohini S, Rao KS, Madhusudhan B, Kumar MU (2008) Tissue culture independent in planta transformation strategy: an Agrobacterium tumefaciens mediated gene transfer method to overcome recalcitrance in cotton (Gossypium hirsutum L.). Journal of cotton science 12: 264-272 .

16. Kumar AM, Reddy KN, Sreevathsa R, Ganeshan G, Udayakumar M (2009) Towards crop improvement in bell pepper (Capsicum annuum L.): Transgenics (uid A:: hpt II) by a tissue culture independent Agrobacterium mediated in planta approach. Scientia Horticulturae 119(4): 362-370. 
17. Kumar AM, Reddy KN, Manjulatha M, Arellano ES, Sreevathsa R, et al (2011) A rapid, novel and high throughput identification of putative bell pepper transformants generated through in planta transformation approach. Scientia Horticulturae 129(4): 898-903.

18. Sankara Rao K, Sreevathsa R, Sharma PD, Keshamma E, Udaya Kumar M (2008) In planta transformation of pigeon pea: a method to overcome recalcitrancy of the crop to regeneration in vitro. Physiol Mol Biol Plants 14(4): 321-328.

19. Keshamma E, Sreevathsa R, Madhusudhan B, Prasad TG (2008) Transformability in field bean (uidA:: nptII) by Agrobacterium tumefaciens-mediated in planta strategy. J Plant Biol 35: 31-37.

20. Manjunatha SB, Suma TC, Sreevathsa R, Devendra R, Udayakumar M (2008) Evaluation of advanced generation transgenic groundnut lines resistant to herbicide glyphosate. Ind J Weed Sci 40(3\&4): 162-165.

21. Neelima MG, Sreevathsa R, Kumar ARV, Gayatri MC (2009) Agrobacterium mediated in planta transformation of chickpea: utility of EPSPS as a selectable marker. Journal of Plant Biology 36(1/2): 5563.

22. Hanjagi PS, Sashidhar VR, Awaji SM, Sreevathsa R (2011) Improvement of salt tolerance in putatively transgenic rice plants overexpressing AVP1, a vacuolar $\mathrm{H}+$ pyrophosphatase. Transgenic Plant Journal 5(1): 43-49.

23. Venkataramaiah N, Ramakrishna SV, Sreevathsa R (2011) Over expression of phytochelatin synthase (AtPCS) in rice for tolerance to cadmium stress. Biologia 66(6): 1060.

24. Awaji SM, Naidu MD, Hanjagi PS, Ramakrishna SV, Sreevathsa R (2011) Possibility of Improved Salt Tolerance in Rice Transgenics Overexpressing pgNHX1. Genes, Genomes and Genomics 6(1): 26-33.

25. Shivakumara TN, Sreevathsa R, Dash PK, Sheshshayee MS, Papolu PK (2017) Over expression of Pea DNA Helicase 45 (PDH45) imparts tolerance to multiple abiotic stresses in chili (Capsicum annuum L.) Scientific Reports 7

26. Keshamma E, Sreevathsa R, Manoj Kumar A, Kumar A,Kumar ARV (2008) A chimeric cry1X gene imparts resistance to Spodoptera litura (Fabricus) and Helicoverpa armigera (Hubner) in transgenic groundnut. Eur J Biosci 2: 53-65.

27. Gowri Neelima M, Ramu SV, Sreevathsa R, Rani A, Kumar ARV (2008) In planta transformation strategy to generate transgenic plants in chickpea: proof of concept with a cry gene. Journal of Plant Biology 35(3): 201-206.

28. Sundaresha S, Kumar AM, Rohini S, Math SA, Keshamma E (2010) Enhanced protection against two major fungal pathogens of groundnut Cercospora arachidicola and Aspergillus flavus in transgenic groundnut over-expressing a tobacco $\beta$ 1-3glucanase. European journal of plant pathology 126(4): 497-508.

29. Kumar AM, Sundaresha S, Sreevathsa R (2009) Resistance to Alternaria leaf spot disease in transgenic safflower (Carthamus tictorius L.) harboring a rice chitinase gene. Transgenic Plnt J 3(1): 113-118.

30. Kumar AM, Sreevathsa R, Reddy KN, Ganesh PT, Udayakumar M (2011) Amenability of castor to an Agrobacterium mediated in planta transformation strategy using a cry $1 \mathrm{AcF}$ gene for insect tolerance. Journal of Crop Science and Biotechnology 14(2): 125-132.

31. Manoj Kumar A, Sundaresha S, Rohini S (2011) Transgenic sunflower (Helianthus annuus L.) with enhanced resistance to a fungal pathogen Alternaria helianthi. Transgenic Plant J 5(1): 50-56.

32. Keshamma E, Sreevathsa R, Kumar AM, Reddy, KN, Manjulatha M (2012) Agrobacterium-mediated in planta transformation of field bean (Lablab purpureus L.) and recovery of stable transgenic plants expressing the cry1AcF gene. Plant Molecular Biology Reporter 30(1): 67-78.

33. Ramu SV, Rohini S, Keshavareddy G, Gowri Neelima M, Shanmugam NB (2012) Expression of a synthetic cry $1 \mathrm{AcF}$ gene in transgenic Pigeon pea confers resistance to Helicoverpa armigera. Journal of Applied Entomology 136(9): 675-687.

34. Rao JP, Agrawal P, Mahmood R, Sreevathsa R, Rao KS (2012) Tissue culture independent transformation of the forage crop sunn hemp (Crotalaria juncea L.): an easy method towards generation of transgenics. Physiol Mol Biol Plants 18(1): 51-57.

\section{Your next submission with Juniper Publishers will reach you the below assets}

- Quality Editorial service

- Swift Peer Review

- Reprints availability

- E-prints Service

- Manuscript Podcast for convenient understanding

- Global attainment for your research

- Manuscript accessibility in different formats ( Pdf, E-pub, Full Text, Audio)

- Unceasing customer service

Track the below URL for one-step submission https://juniperpublishers.com/online-submission.php 